\title{
Efficacy Test of Bio-pesticides against Tobacco Whitefly Bemisia tabaci (Gennadius, 1889) on Tomato Plants in Nepal
}

\author{
Sharma, M. ${ }^{1}$ Budha, P.B. ${ }^{1,2}$ and Pradhan S.B. ${ }^{3}$ \\ ${ }^{1}$ Central Department of Zoology, Tribhuvan University. Kirtipur, Kathmandu, Nepal \\ ${ }^{3}$ Entomology Division, Nepal Agricultural Research Council, Khumaltar, Lalitpur, Nepal. \\ ${ }^{2}$ Corresponding author: prembudha@yahoo.com
}

\begin{abstract}
The efficacy test of bio-pesticides (Lastraw, Racer ${ }^{\mathrm{TM}}$ Pacer $^{\mathrm{TM}}$, Mealikil ${ }^{\mathrm{TM}}$, Nimbecidine, Servo, Biocide Manic, Bio Power, Nico Neem, Uchit, Mighty-Cure, and Bio Magic) was experimented in tomato plants to control Tobacco whitefly Bemisia tabaci population. The results showed that biopesticides viz. Bio Magic (92.67\%), Racer (91.90\%), Pacer (91.50\%), Mealikil (90.84\%) were highly effective following Bio Power (87.53\%) and Biocide Manic (85.8\%) in reducing the population of whitefly over control after third spray. All biopesticides containing insect pathogen Beauveria bassiana, Verticillium lecanii and Metarhizium anisopliae were found effective in reducing the pest population. But the organic products and mineral oil were comparatively less effective.
\end{abstract}

Keywords: Tomato, pathogens, whitefly, pest, bio-pesticides, organic product, biorationals

\section{INTRODUCTION}

Tomato is one of the major commercial vegetable crops (Ghimire et al. 2000/2001) and widely grown in different seasons both in the plains and hills of Nepal (i.e. winter in Tarai and inner Tarai, spring and rainy in the low and mid hills). Tomato production during rainy season in open field condition is very difficult and the production during the season is very low (Pandey et al. 2006) however the difficulty is overcome by the new and modest technology of tomato production inside the plastic house and arrival of hybrid varieties (Chapagain et al. 2011). The annual production of tomatoes in Nepal is 317,657 metric tonnes in an area of 19,724 hectares (CBS 2010). There are several factors limiting the tomato production. The pests and diseases are major factors causing significant loss in crop yield. There are number of serious arthropod pests (Lange \& Bronson 1981) such as aphid, whitefly, spider mite, fruit borer. Whitefly is one of the serious pests in tomato field (Muñiz \& Nombela 2009).

Whiteflies are minute insects generally characterized by having wings covered with wax (Hodges \& Evans 2005, Liburd \& Nyoike 2012). It is a phloem feeding insect that lives predominantly on herbaceous plant (De Barro et al. 2011). It is broadly polyphagous feeding on estimated 600 plant species (Oliveira et al. 2001). Since the early 1980 s, it has caused severe problem to agriculture crops and ornamental plants (OEPP/EPPO 2004). Whitefly was reported as pest of cotton in 1998 in Nepal and now becoming the burning pest, especially in vegetables both in hills and Tarai of Nepal (NARC 2011) and farmers are using chemical pesticides (Bhandari 2012, Karmacharya
2012). The chemical pesticides belonging to synthetic pyrethroids and organophosphate were applied at initial stage of infestation with increased dose and frequency over the year in vegetables (Rijal et al. 2006). More than one-sixth pesticides used by the farmers were extremely hazardous and which were banned for general agriculture use (Shrestha et al. 2010). Farmers were found using pesticides in pest management and they had little or no knowledge on alternative pest management and IPM (Awino 2008) but FFS' farmers were aware found adopting IPM technology (Adhakari et al. 2007). The sharp increase in the use of pesticides resulted in the development of resistance in key pest species so alternative to the chemicals such as microbial and plant products were studied (Rao et al. 2007). Unavailability of biopesticides on time and lack of awareness among farmers are the major constraints of adoption of biopesticides however, IPM FFS farmers are marginally ahead of using biopesticides in Nepal (Jha 2010).

Whitefly infestations can easily go unnoticed until they reach high numbers. It is important to minimize potential infestations by employing all possible control tactics, but present study is mainly focused on the management of whitefly using bio-pesticides especially Neem and Insect pathogens (Beauveria bassiana, Metarhizium anisopliae and Verticillium lecanii)

\section{MATERIAL AND METHODS}

A field experiment was conducted to evaluate the efficacy of biopesticides against whitefly $B$. tabaci on tomato 
under poly-house condition. The field was laid out at the experimental farm of Entomology Division NARC, Khumaltar; Lalitpur under Complete Randomized Block Design during 2012-13. Three replications and twelve treatments with two controls were experimented to evaluate the efficacy different bio-pesticides against $B$. tabaci. Cuttings of tomato (Variety Srijhana) branches about $15 \mathrm{~cm}$ heights were collected from farmers' field containing eggs mass and nymphs. The branches were then dipped in the Rootex (Root developing hormone) and then planted in the experimental plot of area $1.75 \times 1$ square meter with row to row distance of $55 \mathrm{~cm}$ and plant to plant distance of $30 \mathrm{~cm}$ (Fig. 1).
Replication 1

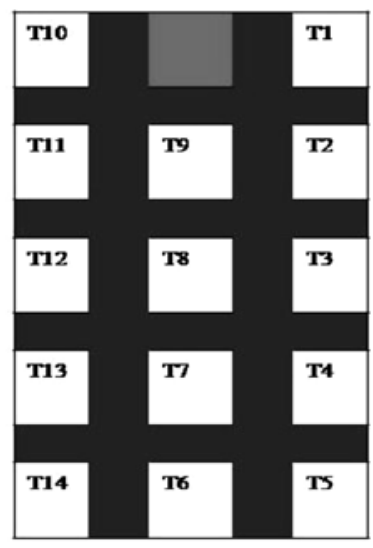

\section{Replication 2}

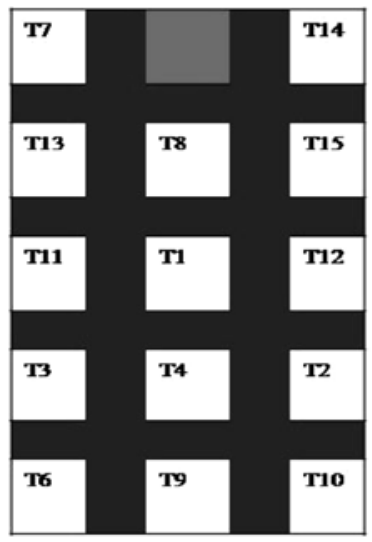

\section{Replication 3}

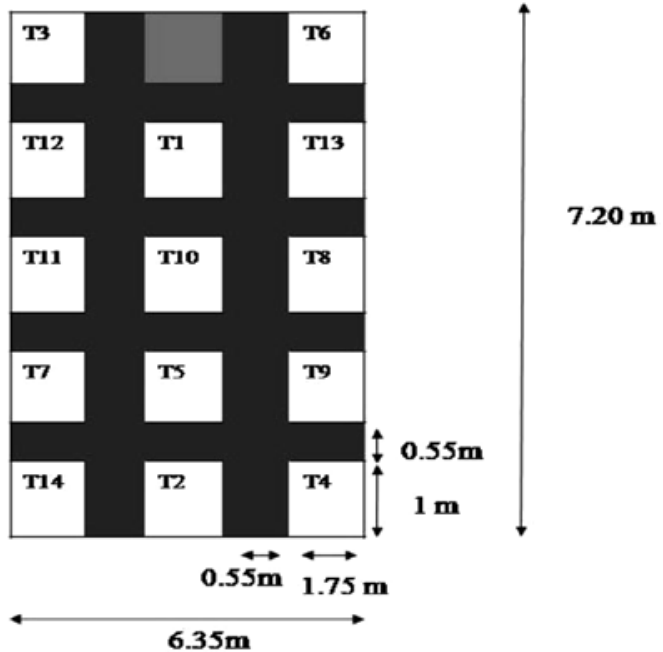

Fig. 1. Layout of the experiment design

Altogether nine tomato plants were planted in each plot. The distance between two plots was $0.55 \mathrm{~m}$. The field was maintained weeds free and irrigation were applied frequently as needed. Following different bio-pesticides (Table 1) were tested to evaluate the efficacy against whitefly.

Table 1. Treatments used in the experiment

\begin{tabular}{lllll}
\hline Treatment & Trade name & Common/Scientific name & a.i. & Dosage \\
\hline 1 & Lastraw & Organic salt & $5 \mathrm{ml} / 1$ \\
2 & Racer $^{\mathrm{TM}}$ & Beauveria bassiana & $1.15 \% \mathrm{wp}$ & $2 \mathrm{gm} .1$ \\
3 & Pacer $^{\mathrm{TM}}$ & Metarhizium anisopliae & $1.15 \% \mathrm{wp}$ & $2 \mathrm{gm} / 1$ \\
4 & Mealikil $^{\mathrm{TM}}$ & Verticillium lecanii & $1.15 \% \mathrm{wp}$ & $2 \mathrm{gm} / 1$ \\
5 & Nimbecidine & Azadirachtin & $0.03 \% \mathrm{EC}$ & $5 \mathrm{ml} / 1$ \\
6 & Servo & Mineral oil & & $15 \mathrm{ml} / 1$ \\
7 & Biocide Manic & Metarhizium anisopliae & $1 \% \mathrm{wp}$ & $5 \mathrm{ml} / 1$ \\
8 & Bio Power & Beauveria bassiana & $1.15 \% \mathrm{wp}$ & $5 \mathrm{ml} / 1$ \\
9 & Nico Neem & Azadirachtin & $0.15 \% \mathrm{EC}$ & $5 \mathrm{ml} / 1$ \\
10 & Uchit & Organic product & & $3 \mathrm{ml} / 1$ \\
11 & Mighty-Cure & Organic product & & $3 \mathrm{ml} / 1$ \\
12 & Bio Magic & Metarhizium anisopliae & $5 \mathrm{gm} / 1$ \\
\hline
\end{tabular}

There were three foliar sprays for all treatments. The first spray was started after 65 days of transplanting and repeated at 12 days interval. The pre-treatment and post-treatment observations were recorded on randomly selected and tagged four plants from each plot. The pre- treatment observation was made $24 \mathrm{hrs}$ before spray. The post observation was done on eleventh day. The population of whitefly nymphs, and adults were counted from three leaves viz. one in each upper, middle and lower leaf of each tagged plant with the help of hand lens 
(20X). The density of nymphs was counted as described by Ohnesorge and Rapp (1986) at the 11th day after spray for succeeding spray.

The percentage of the population reduction due to different treatments over control was calculated using the modified Abbots formula given by Fleming and Retnakaran (1985) as below:

Population reduction over control $(\%)=\{1-(\mathrm{Ta} \times \mathrm{Cb}) /$ $(\mathrm{Tb} \times \mathrm{Ca})\} \times 100$

Where, $\mathrm{Ta}=$ Population in treatment after spray

$\mathrm{Tb}=$ population in treatment before spray

$\mathrm{Ca}=$ Population in control after spray

$\mathrm{Cb}=$ Population in control before spray

\section{RESULTS}

\section{Effect of Different Treatments on the Population of Whitefly Nymphs}

Lastraw $(41.75 \%)$ was found the best effect on reducing the population of nymphs after first spray followed by Mealikil (25.98\%), Bio Power (25.28\%), Racer (23.70\%) and Pacer $(22.51 \%)$. The other treatments included were Biocide Manic (19.16\%), Bio Magic (17.44\%), Servo (9.94\%), Nimbecidine (13.72\%), Nico Neem (13.65\%), Mighty-Cure (8.22\%) and Uchit (12.26\%) (Table 2).

After second spray, Biocide Manic (68.81\%), Nico Neem (64.57\%), Nimbecidine (64\%) and Bio Power (63.51\%) were found to be effective in reducing the population of nymphs.

Table 2. Effect of different treatments against whitefly's nymphs (Mean \pm S.E, \% control)

\begin{tabular}{|l|l|l|l|l|l|l|l|}
\hline Treatments & Before spray & $1^{\text {st }}$ spray & $\%$ & $2^{\text {nd }}$ spray & $\% 1$ & $3^{\text {rd }}$ spray & $\%$ \\
\hline Lastraw & $112.83 \pm 69.28$ & $159.08 \pm 71.79$ & 41.75 & $81.75 \pm 12.0$ & 38.65 & $15.833 \pm 4.44$ & 78.10 \\
\hline Racer & $119.67 \pm 43.47$ & $221.0 \pm 73.32$ & 23.70 & $82.41 \pm 34.83$ & 55.47 & $6.08 \pm 1.30$ & 91.65 \\
\hline Pacer & $176.0 \pm 89.13$ & $330.08 \pm 137.46$ & 22.51 & $128.67 \pm 34.27$ & 53.46 & $9.75 \pm 1.28$ & 91.43 \\
\hline Control & $118.50 \pm 81.16$ & $286.83 \pm 156.30$ & & $240.25 \pm 39.09$ & & $212.5 \pm 71.22$ & \\
\hline Mealikil & $175.50 \pm 85.47$ & $314.42 \pm 51.54$ & 25.98 & $108.25 \pm 34.18$ & 58.89 & $6.17 \pm 2.59$ & 93.55 \\
\hline Nimbicidine & $188.58 \pm 60.51$ & $393.83 \pm 140.23$ & 13.72 & $118.75 \pm 41.34$ & 64.0 & $40.83 \pm 6.52$ & 61.12 \\
\hline Servo & $85.25 \pm 48.47$ & $185.83 \pm 114.17$ & 9.94 & $68.0 \pm 25.49$ & 56.31 & $32.17 \pm 1.92$ & 46.52 \\
\hline Biocide Manic & $161.42 \pm 74.51$ & $315.83 \pm 108.70$ & 19.16 & $82.50 \pm 17.17$ & 68.81 & $7.91 \pm 1.17$ & 89.15 \\
\hline Bio Power & $161.50 \pm 51.40$ & $292.08 \pm 66.08$ & 25.28 & $89.25 \pm 29.62$ & 63.51 & $8.75 \pm 0.38$ & 88.91 \\
\hline Nico Neem & $170.25 \pm 69.01$ & $355.83 \pm 183.92$ & 13.65 & $105.58 \pm 54.18$ & 64.57 & $37.41 \pm 7.98$ & 59.93 \\
\hline Uchit & $151.75 \pm 38.94$ & $332.25 \pm 84.65$ & 12.26 & $126.67 \pm 59.93$ & 53.07 & $54.75 \pm 10.07$ & 51.13 \\
\hline Mighty-Cure & $164.08 \pm 51.57$ & $364.50 \pm 119.34$ & 8.22 & $180.58 \pm 76.56$ & 40.85 & $49.41 \pm 12.67$ & 69.06 \\
\hline Bio Magic & $144.33 \pm 73.77$ & $288.42 \pm 129.37$ & 17.44 & $104.75 \pm 49.91$ & 56.64 & $7.75 \pm 1.52$ & 91.64 \\
\hline
\end{tabular}

Mealikil (58.89\%), Bio Magic (56.64\%), Servo (56.31\%), Racer (55.47\%), Pacer (53.46\%) and Uchit $(53.07 \%)$ were moderate in reducing the population of nymphs while Mighty-Cure (40.85\%) and Lastraw $(38.65 \%)$ were comparatively less effective in reducing the population (Table 2).

After third spray, Mealikil, Racer, Bio Magic, Pacer, Biocide Manic and Bio Power were found effective in reducing the population of nymphs by $93.55,91.65,91.64$, $91.43,89.15$ and 88.91 percent respectively. Mighty-Cure (69.06\%), Nimbecidine (61.12\%), Nico Neem (59.93\%) Uchit (51.13\%) and Servo (46.52\%) were comparatively less effective than above bio-pesticides.

\section{Effect of Different Treatments on the Population of Whitefly Adults}

Nico Neem (83.33\%), Mealikil (80.24\%), Racer (75.95\%), Bio Power (75.17\%), Nimbecidine (74.03\%), Lastraw (71.39\%) and Bio Magic (70.34\%) were the most effective in controlling population of whitefly adults whereas Uchit (67.74\%), Biocide Manic (67.13\%), Pacer
(67.73\%) and Mighty-Cure (67.17\%) were moderate and Servo $(58.43 \%)$ was found comparatively less effective in reducing the population (Table 3 ) after the first spray.

Bio Magic (81.61\%), Bio Power (78.79\%), Pacer (77.18\%), Racer (76.63\%), Mealikil (73.67\%), Biocide Manic (74.16\%) and Servo (72.08 \%) were the most effective in reducing the population of adult over control after the second spray. The moderate impacts were included Lastraw (64.15\%), Nimbecidine (63.48\%) and Nico Neem (53\%) and Uchit (50.30\%) and Mighty-Cure $(47.90 \%)$ were less effective in reducing the population of whitefly over the control (Table 3).

Bio Magic (92.67\%), Racer (91.90\%), Pacer (91.50\%), Mealikil (90.84\%), Bio Power (87.53\%) and Biocide Manic $(85.8 \%)$ were highly effective in reducing the population of whitefly over control after third spray, Nimbecidine (76.96\%), Nico Neem (61.28\%) Lastraw, $(59.42 \%)$ and Mighty-Cure $(58.59 \%)$ were moderate and Uchit $(51.61 \%)$ and Servo (38.01\%) were found less effective against adult whitefly control (Table 3 ). 
Efficacy Test of Bio-pesticides against Tobacco Whitefly Bemisia tabaci (Gennadius, 1889) on Tomato Plants in Nepal

Table 3. Effect of different treatments against whitefly's adults (Mean \pm S.E, $\%$ control)

\begin{tabular}{|l|c|c|c|c|c|c|c|}
\hline \multicolumn{1}{|c|}{ Treatments } & Before spray & $\mathbf{1}^{\text {st }}$ spray & $\mathbf{\%}$ & $\mathbf{2}^{\text {nd }}$ spray & $\mathbf{\%}$ & $\mathbf{3}^{\text {rd }}$ spray & $\mathbf{\%}$ \\
\hline Lastraw & $26.83 \pm 3.66$ & $12.50 \pm 4.26$ & 71.39 & $20.0 \pm 4.64$ & 64.15 & $6.92 \pm 0.73$ & 59.42 \\
\hline Racer & $29.58 \pm 9.98$ & $11.58 \pm 4.91$ & 75.95 & $12.08 \pm 1.72$ & 76.63 & $0.83 \pm 0.08$ & 91.90 \\
\hline Pacer & $34.42 \pm 12.79$ & $18.08 \pm 3.04$ & 67.73 & $18.41 \pm 0.98$ & 77.18 & $1.33 \pm 0.36$ & 91.50 \\
\hline Mealikil & $31.08 \pm 6.77$ & $10.0 \pm 2.78$ & 80.24 & $11.75 \pm 3.59$ & 73.67 & $0.91 \pm 0.22$ & 90.84 \\
\hline Nimbecidine & $39.41 \pm 19.56$ & $16.66 \pm 7.20$ & 74.03 & $27.16 \pm 7.39$ & 63.48 & $5.33 \pm 1.08$ & 76.96 \\
\hline Servo & $24.50 \pm 5.64$ & $16.58 \pm 8.48$ & 58.43 & $20.66 \pm 6.78$ & 72.08 & $10.91 \pm 0.82$ & 38.01 \\
\hline Biocide Manic & $21.33 \pm 6.83$ & $11.42 \pm 6.54$ & 67.13 & $13.16 \pm 0.30$ & 74.16 & $1.58 \pm 0.50$ & 85.8 \\
\hline Bio Power & $34.833 \pm 7.44$ & $14.08 \pm 4.50$ & 75.17 & $13.33 \pm 1.10$ & 78.79 & $1.41 \pm 0.36$ & 87.53 \\
\hline Nico Neem & $43.92 \pm 33.17$ & $11.91 \pm 1.80$ & 83.33 & $25.0 \pm 8.04$ & 53.00 & $8.25 \pm 1.08$ & 61.28 \\
\hline Uchit & $42.83 \pm 10.91$ & $22.50 \pm 10.71$ & 67.74 & $49.91 \pm 3.53$ & 50.30 & $20.58 \pm 6.16$ & 51.61 \\
\hline Mighty-Cure & $46.91 \pm 14.46$ & $25.08 \pm 8.97$ & 67.16 & $58.33 \pm 13.66$ & 47.90 & $20.58 \pm 4.83$ & 58.59 \\
\hline Bio Magic & $26.91 \pm 10.74$ & $13.00 \pm 0.76$ & 70.34 & $10.66 \pm 1.59$ & 81.61 & $0.66 \pm 0.17$ & 92.67 \\
\hline
\end{tabular}

\section{DISCUSSION}

The efficacy of different treatments was observed on the basis of reduction of number of nymphs and adults. The nymphs and adults population of whitefly were reduced by 91.65 and 91.90 percent respectively by Racer and 88.91 and 87.53 percent by Bio Power after the third successive spray in comparison to control. Both Racer and Bio Power belong to insect pathogen Beauveria bassiana. According to Faria and Wraight (2001) B. bassiana provides good control of whitefly both in green house and field crops. This was supported by the study of Liu and Stansly (2009) where treatment with BotaniGuard ${ }^{\mathrm{TM}}$ (B. bassiana) killed $76.7-91.6 \%$ of whitefly $B$. tabaci nymphs. Application of $B$. bassiana at the dose of 1 $\mathrm{mgml}^{-1}$ killed $100 \%$ of B. tabaci adults (Zaki 1998). Bioassay method using B. bassiana on melon leaves as substrate for egg and nymphs of the Bemisia tabaci biotype B shows that average nymphal mortality at day seven post spray reached a maximum value of $25.7 \%$ and average mortality at day 14 post sprays varied from $6.1 \%$ to $92.3 \%$ (Vicentini et al. 2001). Different isolates of $B$. bassiana at the concentration of $10^{7}$ on the fourth instar nymphs gave 3-85\% mortality (Quesada-Moraga et al. 2006). All these results are in support with the present study where population reduction by $B$. bassiana was found between 18 percent which was lowest in case of eggs to over 90 in case of nymphs and adults.

Efficacy of Verticillium lecanii (Mealikil) was found similar to B. bassiana. It reduced the number of nymphs and adults population by 93.55 and 90.84 percent respectively after the third successive spray. It was found effective in reducing the population of whitefly in tomato crops (NARC 2011). Andrew et al. (2008) found mortality of $B$. tabaci was significantly different between different isolate varying from $87-56 \%$. Wang et al. (2007) showed that nymph was the most susceptible stage and adult being the second, this result supports the present study. The result was supported by (Cuthbertson et al. 2005) where nymphs were found to be the most susceptible. Concentration of 0.25 of $V$. lecanii caused $100 \%$ mortality of B. tabaci (Karthikeyan \& Selvanarayanan 2011) and concentration of $3.2 \times 10^{6}$ conidia per $\mathrm{ml}$ of $\mathrm{V}$. lecanii under in vitro condition was 92 to 100 percent of the nymphal mortality (Nier et al. 1993).

Three different products of Metarhizium tested were Pacer, Biocide Manic and Bio Magic. Effectiveness in reducing the population of nymphs and adults by Pacer, Biocide Manic and Bio Magic was 91.43 and 91.50; 89.15 and 85.8 ; and 91.64 and 92.67 percent respectively after third spray. M. anisopliae (Daman) was found effective in reducing the population of whiteflies where the numbers of nymphs were very few (NARC 2011). Batta (2003) when tested the fungus M. anisopliae under field condition the mortality of whitefly ranged from 30$92.2 \%$ which was comparatively low than the results of this study. When the formulated and non-formulated forms of Metarhizium were tested against immature stage of $B$. tabaci the mortality percent was 92.26 and 27.94 (Zaid 2002). M. anisopliae $\left(2 \times 10^{5}\right.$ spores $\left.1^{-1}\right)$ proved to be least effective whereas Nimbecidine 0.03 EC $(5 \mathrm{ml}$ $1^{-1}$ ) and Neem seed kernel extract (NSKE) 5 percent were found in the middle order of effectiveness (Bairwa et al. 2006).

Efficacy of neem formulations was less than insect pathogens used against the population of whitefly. Among the neem products, Nico Neem reduced the population of whitefly nymphs and adults by 59.93 and 61.28 percent respectively after the third successive spray while the 
Nimbecidine reduced the population by 61.12 and 76.96 percent respectively. The reduction in the population of B. tabaci in all concentration of neem derivatives was $50-60 \%$ (Jat and Jeyakumar 2006) which was quite similar to the present study while Jayaraj et al. (1986) found NSKE at 5\% and neem oil @ 5\% caused 93.7 and 90.3 percent mortality of nymphal stage of $B$. tabaci respectively. Nimbalkar (1993) also found that NSKE @ 5\% and neem oil@2\% gave considerable reduction in adult and nymphal population of $B$. tabaci. Spraying of neem oil@ 0.5\% and NSKE 5\% were found superior over chemical check moncorotophos (Rosaiah 2001). The neem based insecticides viz., NSKE (3\%), Achook $(0.3 \%)$, Neem gold $(0.3 \%)$ and Nimbecidine $(0.3 \%)$ were found comparable to moncorotophos and dimethoate in all respects (Rajnish et al. 2006). Neem Azal-T/S (NA, at $20 \mathrm{~g}$. a.i. ha-1) reduced the population of $B$. tabaci by $61 \%$ when conducted in three similar field experiments in egg plant (EL Shafie and Basedow 2003) which is similar to the result of the present study where Nico Neem reduced the population by $61 \%$. The reduction in the population of the whitefly is due to the anti-feedant and deterrent effect of neem which had forced the test insects to leave the locality or chronic effect of the neem compounds (Khattak et al. 2006). At dose-rate of 7 and $10 \mathrm{ml}$ Neem Azal (-T/S(1\%) Azadirachtin induced an immature mortality of 32 and $44 \%$ respectively whereas seven days post application under greenhouse conditions, mortality declined to 5 and $7 \%$ respectively (Kumar \& Poehling 2006). Kumar (2008) using a commercial neem product (Neem Azal-U 17\%) against B. tabaci on tomatoes found that the fresh neem residue had the strongest effect in all parameters which decreases gradually over time. The bio efficacy was recorded from 1-7days where the immature mortality was reduced from $88.20 \%-45.01 \%$. Among the eight neem based formulations tested against whitefly causing leaf curl disease in tomato, Nimbecidine proved most promising in minimizing the leaf curl incidence $(08.33$ and $08.73 \%)$ in both years followed by Neemazal, Neemgold, RD-9-Repelin, Bioneem, Neemark, Neemta-2100 and Achook (Kuldeep et al. 2009).

Lastraw (composition of Potassium salt) reduced the population of whitefly nymphs and adults by 78.10 , and 59.42 percent respectively where the population reduction by Servo (petroleum oil) was 46.52 and 38.01 percent respectively. Certis spraying oil (Petroleum oil $1 \mathrm{ml} / 100 \mathrm{ml}$ water, Certis UK) resulted in high second instar larval mortality (93\%). Certis spraying oil resulted in a high efficacy against adult $B$. tabaci with $100 \%$ mortality on Poinsettia plants (Cuthbertson et al. 2009). The result of the Cuthbertson et al. (2009) is not in support of the present study. Agricultural spray oil is effective against whiteflies however in combination with these insecticides was observed to be more effective (Mote 1978).

Mighty-Cure, one of the organic products reduced the population of whitefly nymphs and adults by 69.06 and 58.59 percent where Uchit which is tested for the repellent activity of whitefly reduced the population of whitefly nymphs and adults by 51.13 and 51.61 percent respectively. Similar result was found in NARC (2011) where the organic product Mighty-Cure, Margosome and Jibatu were found less effective than $V$. lecanii and $M$. anisopliae but effective over control.

\section{CONCLUSION}

Among the different biorationals used, insect pathogens were found to be effective in reducing the population. Among the insects pathogens Beauveria bassiana (Racer and Bio Power), Verticillium lecanii (Mealikil) and Metarhizium anisopliae (Pacer, Biocide Manic and Bio Magic) were comparatively effective in reducing the pest population. Although during the period of first and second spray the percent reduction over control was quite less, but after the third spray their effectiveness was impressive. Treatments belonging to the neem products (Nico Neem and Nimbecidine) were moderate in their effectiveness while Lastraw was found quite similar in their effectiveness with the neem products. Among the organic products Mighty-Cure and Uchit were less effective than above mentioned products but effective than Servo (Petroleum oil).

\section{REFERENCES}

Adhikari, K.P., Gupta, N.P., Dongol, B.B.S. and Thapa, R.B. 2007. Effectiveness of integrated pest management technology through farmers' field schools on vegetable production in Nawalparasi and Kavrepalanchok districts of Nepal. IAAS Research Advances 2: 119-126.

Andrew, C.G.S., Blackburn, L.F., Northing, P., Luo, W., Cannon, R.J.C. and Keith, F.A.W. 2008. Further compatibility tests of the entomopathogenic fungus, Lecanicillium muscarium with conventional insecticide products for control of sweetpotato whitefly, Bemisia tabaci on poinsettia plants. Insect Science 15 (4): 355-360.

Awino, O.I. 2008. Tomato Production Practices in Kirinyaga District and Assessment of Pest Management Options at KARI - Thika.M.Sc. Thesis. Department of Zoology, Jomo Kenyatta University of Agriculture and Technology.

Bairwa, D.K., Sharma, J.K. and Kumawat, K.C. 2006. Efficacy of insecticides, biopesticides and plant products against whitefly, Bemisia tabaci on 
Moth bean, Vigna aconitifolia. Indian Journal of Plant Protection 34(2): 210-212.

Batta, Y.A. 2003. Production and testing of novel formulation of entomopathogenic fungus Metarhizium anisopliae (Metschinkoff) Sorokin (Deuteromycotina: Hyphomycetes). Crop Protection 22: 415-422.

Bhandari, P.S. 2012. Farmers perception about gains from integrated pest management Farmer Field School. International Journal of Agricultural Science, Research and Technology 2(3): 137142.

CBS. 2010. Nepal Vegetable Crops Survey 2009-10, A Statistical Report. Central Bureau of Statistics, Kathmandu, Nepal.

Chapagain, T.R., Khatri, B.B. and Mandal, J.L. 2011. Performance of tomato varieties during rainy season under plastic house conditions. Nepal Journal of Science and Technology 12: 17-22.

Curthbertson, A.G.S., Walters, K.F.A. and Northing, P. 2005. The susceptibility of immature stages of Bemisia tabaci to the entomopathogenic fungus Lecanicillium muscarium on tomato and verbena foliage. Mycopathologia 159: 23-29.

Cuthbertson, A.G.S., Blackburn, L.F., Northing, P., Luo, W., Cannon, R.J.C. and Walters, K. F. A. 2009. Leaf dipping as an environmental screening measure to test chemical efficacy against Bemisia tabaci on Poinsettia plants. International Journal Environmental Science and Technology 6(3): 347-352.

De Barro, P., Liu, S., Boykin, L.M. and Dinsdale, A.B. 2011. Bemisia tabaci: A Statement of Species Status. Annual Review of Entomology 56: 1-19.

EL Shafie, H.A.F. and Basedow, T. 2003. The efficacy of different neem preparation for the control of insect damaging potatoes and eggplants in the Sudan. Crop Protection 22: 1015-1021.

Fleming, R. and Retnakaran, A. 1985. Evaluating single treatment data using modified Abbot's formula with reference to insecticides. Journal of Economic Entomology 78(6): 1179-1181.

Ghimire, S.R., Subedi, P.P. and Green, S.K. 2000/2001. Status of Tomato yellow leaf curl virus in tomato in the western hills of Nepal. Nepal Agriculture and Research Journal 4 \& 5: 1-4.

Hodges, G.S. and Evans, G.A. 2005. An Identification Guide to the Whiteflies (Hemiptera: Aleyrodidae) of the Southern United States. Florida Entomologists 88(4): 518-534.

Jat, M.C. and Jeyakumar, P. 2006, Bioefficacy of botanicals and bioagents on sucking pests of cotton. Annals of Plant Protection Science 14 (1): 8-10.

Jha, R.K. 2010. Farmer-level use of biopesticides in Nepal. Journal of the Plant Protection Society 2: 116-126.

Karmacharya, S. 2012. Pesticide use in agriculture and its socio-economic context, A case study of Panchkhal area, Kavre, Nepal. International Journal of Scientific and Technology Research 1(9): 17-20.

Karthikeyan, A. and Selvanarayanan, V. 2011. In vitro Efficacy of Beauveria bassiana (Bals.) Vuill. and Verticellium lecanii (Zimm.) Viegas against selected insect pest of cotton. Resent Research in Science and Technology 3(22): 142-143.

Khattak, M.K., Mamoon-ur-Rashid, H.S.A.S. and Islam, T. 2006. Comparative effect of neem (Azadirachta indica A. Juss) oil, neem seed water extract and Baythroid ${ }^{\mathrm{TM}}$ against whitefly, jassids and thrips on cotton. Pakistan Entomology 28(1): 31-37.

Kuldeep, S., Singh, D.K. and Raju, S.V.S. 2009. Bioefficacy of certain neem based formulations against whitefly, Bemisia tabaci Gennadius causing leaf curl disease in tomato. Indian Journal of Entomology 71(2): 165-167.

Kumar, P. 2008. Studies on loss of bioefficacy of two indirect neem application over time (seed and soil) against Bemisia tabaci (Homoptera: Aleyrodidae) under semi field condition. Journal of Asia Pacific Entomology 11: 185-190.

Kumar, P. and Poehling, H.M. 2006. Persistence of soil and foliar azadirachtin treatments to control sweetpotato whitefly Bemisia tabaci Gennadius (Homoptera: Aleyrodidae) on tomatoes under controlled (laboratory) and field (netted greenhouse) condition in the humid tropics. Journal of Pest Science 79: 189-199.

Lange, W.H. and Bronson, L. 1981. Insect pests of tomatoes. Annual Review of Entomology 26:345371.

Liburd, O.E. and Nyoike, T.W. 2012. Biology and management of whiteflies in sustainable field production of cucurbits. University of Florida IFAS extension 3pp.

Mote, U.N. 1978. Effect of few insecticides alone and in combination with agricultural spray oil on the control of whitefly (Bemisia tabaci Gennadius) population and incidence of leaf curl virus. Indian Journal of Plant Protection 6(1): 19-22. 
Muñiz, M. and Nombela, G. 2009. Research on tomato resistance to the virus-transmitter whitefly Bemisia tabaci undertaken during the last year in Madrid (Spain). In: Saygili, H., Sahin, F., and Aysan, Y. eds. Proceedings of the Second International Symposium on Tomato Diseases. Acta Horticulturae 808: 175-179.

NARC 2011. Action research on technology generation for the management of whitefly, Bemisia tabaci (Gennadius). Annual Technical Report 200911. Entomology Division, Nepal Agricultural Research Council, Khumaltar, Lalitpur 29-30.

Nier, T., River, F. and Bermudez, J.C. 1993. First report of Mexico on the isolation of Verticillium lecanii from whitefly and in vitro pathogenecity tests on this insect. Revista Mexican De Micologia 7: 149-156.

Nimbalkar, S.A., Khodke, S.M., Taley, Y.M. and Patil, K.J. 1993. Bioefficacy of some new insecticides including neem seed extract and neem oil for control of whitefly, Bemisia tabaci in cotton. Botanical Pesticides in Integrated Pest Management 256-260.

OEPP/EPPO 2004. Diagnostic protocols for regulated pests. European and Mediterranean Plant Protection Organization Bulletin 34: 281-288.

Ohnesorge, B. and Rapp, G. 1986. Method for estimating the density of whitefly nymphs (Bemisia tabaci Genn.) in cotton. Tropical Pest Management 32(3): 207-211.

Oliveria, M.R.V., Henneberry, T.J. and Anderson, P. 2001. History, current status, and collaborative research projects for Bemisia tabaci. Crop Protection 20: 709-723.

Quesada-Moraga, E., Maranhao, E.A.A., ValverdeGarcía, P. and Santiago-Álvavez, C. 2006. Selection of Beauveria bassiana Isolates for the Control of Whiteflies Bemisia tabaci and Trialeurodes vaporarioum on the basis of their virulence, thermal requirements and toxicogenic activity. Biological Control 36: 274-287.

Rajnish, K., Ali, Shamshad, Rizvi, S.M.A. 2006. Efficacy of insecticides and neem against Bemisia tabaci Genn. and yellow mosaic virus in mung bean. Annal of Plant Protection Sciences 14(2): 431434.
Rao, G.V.R., Rupela, O.P., Rao, V.R. and Reddy, Y.V.R. 2007. Role of biopesticides in crop protection: present status and future prospects. Indian Journal of Plant Protection 35(1): 1-9.

Rijal, J.P., Malla, R.K., Rawat, P.R., Tiwari, S. and GC, Y.D. 2006. A preliminary study on the practices of insect pest management at Sukranagar VDC, Chitwan: A case study. Proceedings of National IPM Workshop of Plant Protection Society of Nepal, 25-26 August, Kathmandu. 10pp.

Shrestha, P., Koirala, P. and Tamrakar, A.S. 2010. Knowledge, practice and use of pesticides among commercial vegetable growers of Dhading district, Nepal. The journal of Agriculture and Environment 11: 95-100.

Vicentini, S., Faria, M. and Olivera, M.R.V. 2001. Screening of Beauveria bassiana (Deuteromycotina: Hyphomycetes) isolates against nymphs of Bemisia tabaci (Genn.) biotype B (Hemiptera: Aleyrodidae) with description of a new bioassay method. Neotropical Entomology 30(1): 97-103.

Wang, L., Huang, J., You, M., Guan, X. and Bo Liu, B. 2007. Toxicity and feeding deterrence of crude toxin extracts of Lecanicillium (Verticillium) lecanii (Hyphomycetes) against sweetpotato whitefly, Bemisia tabaci (Homoptera: Aleyrodidae). Pest Management Science 63: 381-387.

Zaid, D. 2002. Bio-control of tobacco whitefly Bemisia tabaci using the entomopathogenic fungus Metarhizium anisopliae. M.Sc. Thesis. Faculty of graduate studies, Najah National University, Nablus, Palestine.

Zaki, H.N. 1998. Efficiency of the entomopathogenic fungus, Beauveria bassiana (Bals), against Aphis crassivora Koch and Bemesiatabaci, Gennadius. Journal of Applied Entomology 22: 397-399. 